\title{
THE RADIOLOGICAL PATTERN OF CHILDHOOD PNEUMONIA IN THE UNDER-5-AGE GROUP IN NORTH-WESTERN NIGERIA
}

\footnotetext{
${ }^{1}$ Saidu SA , ${ }^{1}$ Maaji SM, ${ }^{2}$ Nzeh DA, ${ }^{2}$ Jiya NM.

Departments of ${ }^{1}$ Radiology and ${ }^{3}$ Paediatrics, Usmanu Danfodiyo University Teaching Hospital, Sokoto, Nigeria; Department of ${ }^{2}$ Radiology, University of Ilorin, Ilorin, Nigeria.

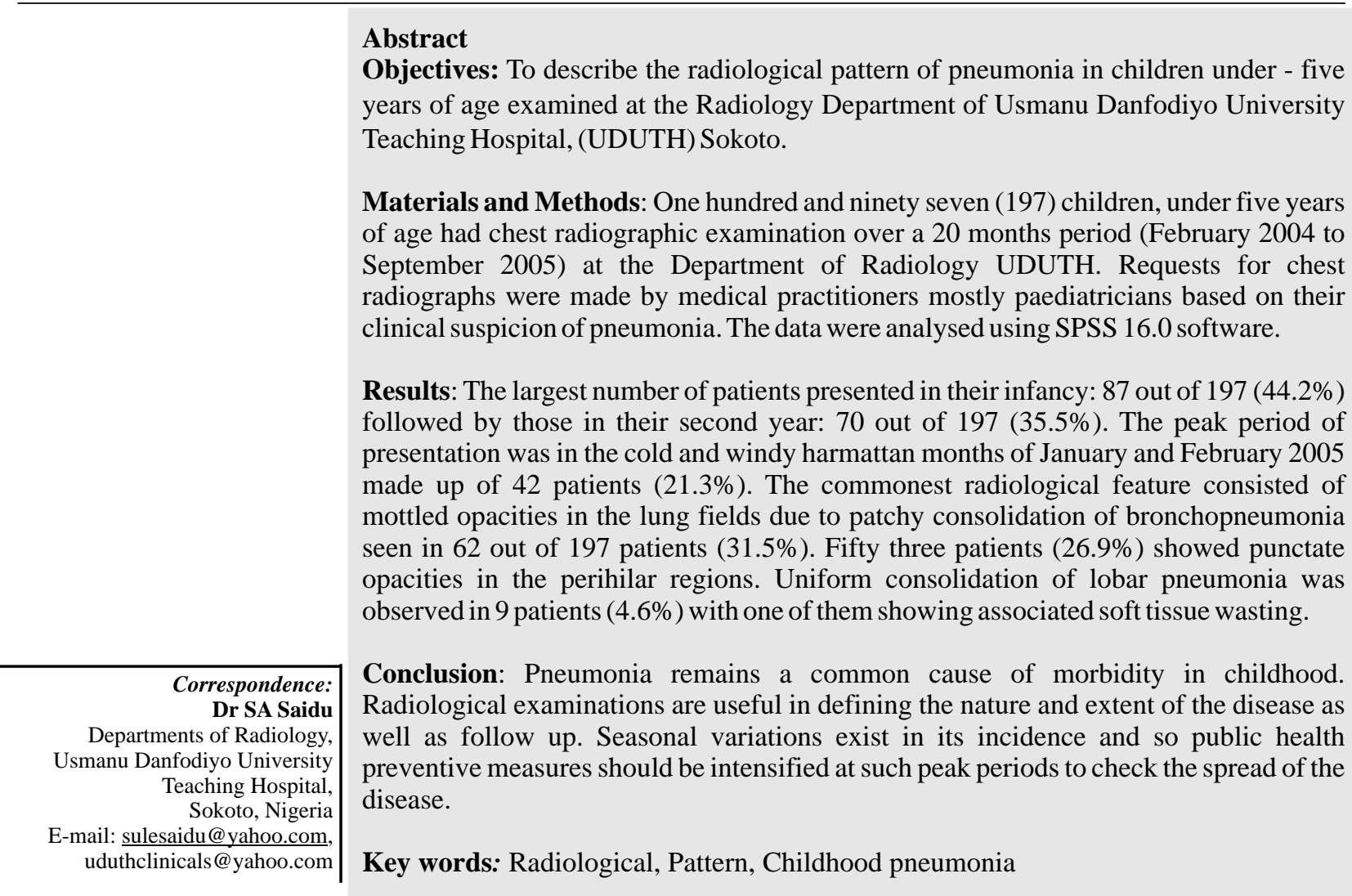

\section{INTRODUCTION}

$\mathrm{P}$ neumonia is one of the leading causes of morbidity, hospitalization and mortality in both industrialized and developing countries. ${ }^{1-3}$ The incidence of pneumonia, however, is substantially greater among children in developing countries. ${ }^{4-6}$ Pneumonia accounts for a quarter of all deaths in under -5 children, many of which occur in children under 2 years of age especially infants. ${ }^{7,8}$ In fact, studies in the Northcentral and North -eastern parts of Nigeria revealed that pneumonia is the second cause of deaths among such children. , $^{, 10}$

It may be caused by viruses, bacteria or concomitant viral-bacterial infection; fungal and atypical infection may also occur especially in immuno-compromised patients. ${ }^{11,12}$

The commonest causes of childhood pneumonia include: Streptococcus pneumoniae,
Staphylococcus aureus and Haemophilus influenzae. Other causative organisms are Klebsiella and other gram negative organisms, Respiratory syncytial virus, Rhinovirus, Mycoplasma pneumoniae, Pneumocystis carinii and Chlamydia spp. ${ }^{11,13,14}$

In pneumonia blood culture is seldom positive and the sensitivity and specificity of clinical signs, even in developed countries, were until recently often not high enough. ${ }^{15}$ This coupled with the poor definition of the epidemiology of pneumonia made the World Health Organization to recommend standardized chest radiograph interpretation to improve the approach to its diagnosis and management. ${ }^{16}$ The role of imaging in pneumonia is to confirm the presence, extent, anatomical location and evaluate progress or complication(s). ${ }^{17}$

The objective of this study is therefore to 
describe the radiological pattern of pneumonia in children less than five years of age with a view to suggesting better ways of diagnosing the disease.

\section{MATERIALS AND METHODS}

This was a descriptive retrospective crosssectional study of 197 children, under 5 years of age who had chest radiographic examinations over a 20 -month period between February 2004 and September 2005 at the Department of Radiology of UDUTH, Sokoto, Nigeria. UDUTH is the only Teaching Hospital in Sokoto, serving at least other three states of Kebbi, Zamfara and Katsina, and part of neighboring Niger Republic. Request for chest radiographs were made by medical practitioners particularly paediatricians based on the clinical suspicion of pneumonia. The socio - demographic and clinical data were obtained from the request cards and where necessary the patient medical record file. The radiologic findings as reported by the radiologists were also similarly obtained. The data were analysed using SPSS 16.0 software.

\section{RESULTS}

The children were aged 10 days to 5 years with mean age of 18.14 months, $\mathrm{SD}=13.19$. Of the total of 197 patients, 107 were males while 90 were females with M: F ratio of 1.2:1.

The largest number of patients presented in their infancy: 87 out of 197 (44.2\%) followed by those in their second year: 70 out of 197 (35.5\%). The detail of the age distribution of the patients is as in Table 1. The peak period of presentation was in the cold and windy harmattan months of January and February 2005 made up of 42 patients (21.3\%). The cold rainy months of August and September also had significant number of patients as shown in Figure 1.

The commonest radiological feature consisted of mottled opacities in the lung fields due to patchy consolidation of bronchopneumonia seen in 62 out of 197 patients (31.5\%). Fifty three patients $(26.9 \%)$ showed punctate opacities in the perihilar regions. Uniform consolidation of lobar pneumonia was observed in 9 patients (4.6\%). The various radiological appearances encountered are described in Table 2.

\section{DISCUSSION}

Pneumonia related mortality and morbidity are high in the under-5 children, with the infant age group most affected, especially in the tropics. ${ }^{8,18}$ We found the highest number of patients presenting in their first two years of life. This is in agreement with other studies in other regions of Nigeria and abroad..$^{16,19-21}$ The incidence of childhood pneumonia in this study tended to decrease with increasing age as shown in Table 1. This finding is similar to what was obtained in Ilorin, North- central part of Nigeria. ${ }^{18}$ This is presumably because the older the child the more matured the pulmonary system and the greater the immunity acquired against developing pneumonia.

The peak period of presentation was in the cold and windy harmattan months of January and February followed by the cold rainy months of August and September as shown in figure 2. Fagbule and her colleagues also found two peaks occurring at similar periods in another study in central part of Nigeria. ${ }^{22}$ The tendency for seasonal variation was also found in the study carried out by Chan et al in Malaysia. ${ }^{23}$ Radiological imaging plays a crucial role in the detection and management of patients with pneumonia., ${ }^{14,}{ }^{19}$ Chest radiography is the imaging technique of choice because of its availability, low radiation dose and excellent cost benefit ratio. ${ }^{16,24}$

In daily practice, radiographs are used to confirm the clinical diagnosis of pneumonia, characterize the extent and severity of disease, search for complications such as empyema, monitor response to therapy and examine for differential diagnoses. ${ }^{15}$

The commonest radiological finding in this study consisted of mottled opacities in the lung fields followed by punctate opacities in the perihilar regions. This is in consonance with the study by Fagbule and his colleagues. ${ }^{19} \mathrm{~A}$ number of patients also showed combination 
Table i : Age distribution of the patients

\begin{tabular}{ccc}
\hline $\begin{array}{c}\text { Age } \\
\text { (in months) }\end{array}$ & $\begin{array}{l}\text { Number } \\
\text { of Patients }\end{array}$ & \begin{tabular}{c}
$\%$ \\
\hline $0-12$
\end{tabular} \\
$13-24$ & 70 & 44.2 \\
$25-36$ & 19 & 35.5 \\
$37-48$ & 12 & 9.6 \\
$49-60$ & 9 & 6.1 \\
Total & 197 & 100 \\
\hline
\end{tabular}

of features which included pleural effusion, pneumatocoeles and lymphadenopathy. A detail of the radiological appearances is shown in Table 2. We also note that a significant proportion of our patients had normal radiographic findings $(22 \%)$. This is much higher than the $2 \%$ in the work by Fagbule, Adedoyin and Nzeh. ${ }^{19}$ Our finding may be due to any of the following reasons: infection confined to the upper respiratory tract, early presentation for radiographic examination before features of the disease are established and radiographically evident, and perhaps indiscriminate use of antibiotics even before confirmation of the diagnosis. Viral pneumonia may also show normal finding on

Table ii: Radiological findings in 197 children with pneumonia

\begin{tabular}{lc}
\hline Radiological findings & Frequency (\%) \\
\hline Mottled opacities & $67(34.0)$ \\
$\begin{array}{l}\text { Perihilar opacities } \\
\text { Normal }\end{array}$ & $59(29.9)$ \\
$\begin{array}{l}\text { Lobar pneumonia } \\
\text { Prominent bronchovascular }\end{array}$ & $9(4.6)$ \\
$\begin{array}{l}\text { Markings } \\
\text { Mottled opacities+lobar }\end{array}$ & $6(3.0)$ \\
$\begin{array}{l}\text { Consolidation } \\
\text { Mottled opacities+pleural }\end{array}$ & $5(2.5)$ \\
$\begin{array}{l}\text { Effusion } \\
\text { Mottled opacities+ } \\
\text { pneumatocoele }\end{array}$ & $1(0.5)$ \\
$\begin{array}{l}\text { Lobar pneumonia+pleural } \\
\text { effusion }\end{array}$ & $1(0.5)$ \\
$\begin{array}{l}\text { Pleural effusion+ } \\
\text { underlying collapse }\end{array}$ & $1(0.5)$ \\
$\begin{array}{l}\text { Perihilar opacities+ } \\
\text { hilar adenopathy }\end{array}$ & $1(0.5)$ \\
$\begin{array}{l}\text { Mottled opacities+ } \\
\text { hilar and paratracheal } \\
\text { lymphadenopathy }\end{array}$ & $1(0.5)$ \\
$\begin{array}{l}\text { Perihilar opacities+ } \\
\text { pleural effusion+ } \\
\text { pneumatocoele }\end{array}$ & $1(0.5)$ \\
Total & $1(0.5)$ \\
\hline
\end{tabular}

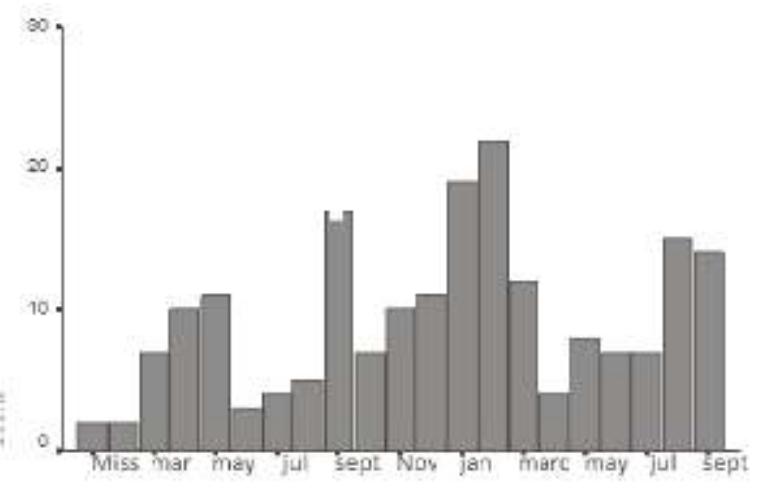

Figure 1: The Bar Chart showing the seasonal distribution of Pneumonia in Childhood: No of cases per Month.

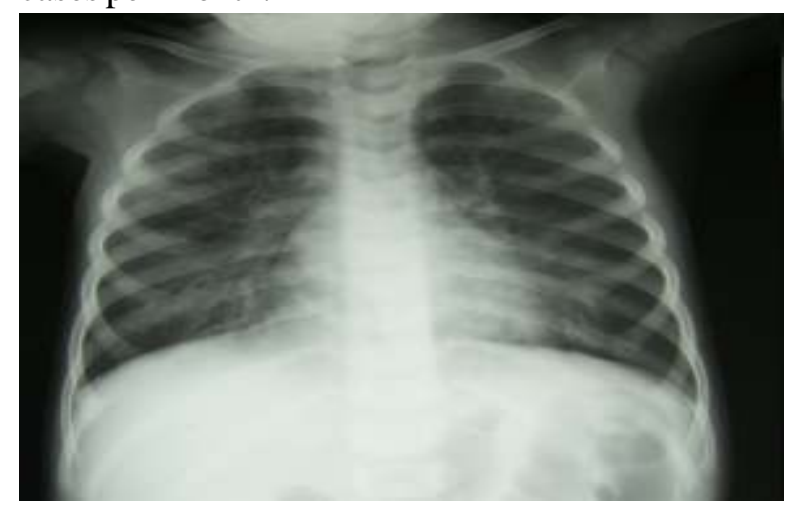

Figure 2: Chest radiograph showing bilateral mottled opacities worse in the perihilar regions in a 2-year-old female child

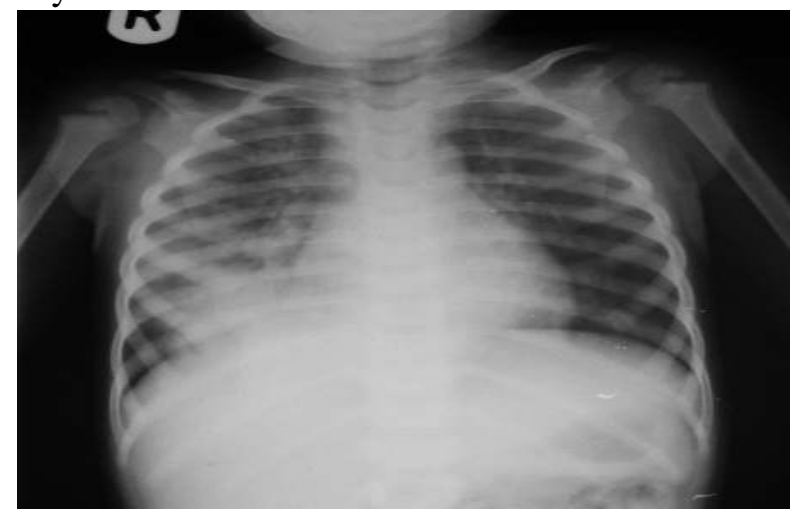

Figure 3: Chest radiograph showing bilateral mottled pulmonary opacities, with some coalescing, worse on the right in an 18 months old

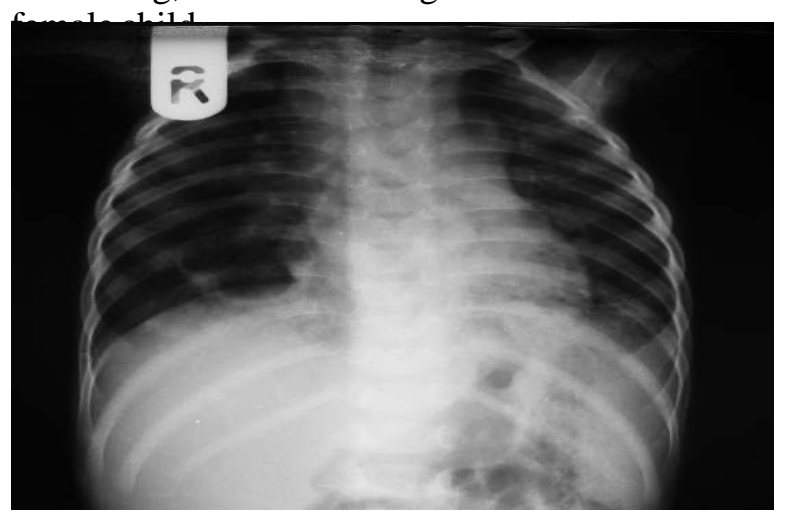

Figure 4: Chest radiograph of a 12 months old male child showing bilateral perihilar opacities with a pneumatocele in the right lower lung zone medially 


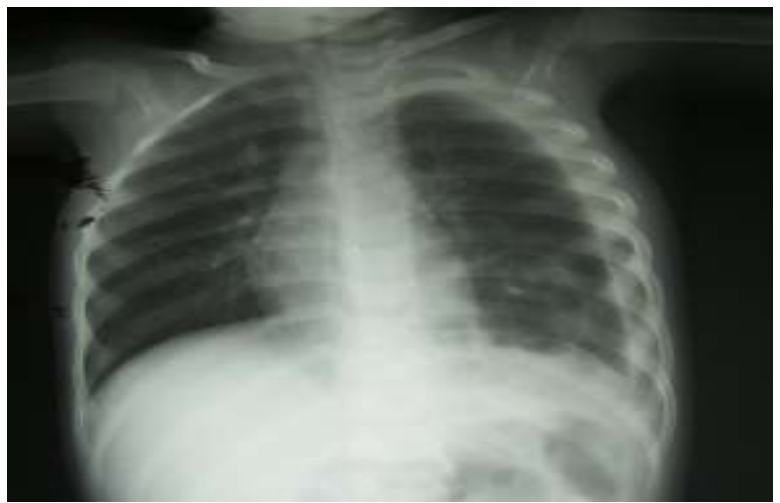

Figure 5: Chest radiograph of a 21 months old female child showing bilateral perihilar infective opacities with left sided lamellar effusion and left lower zone pneumatocele

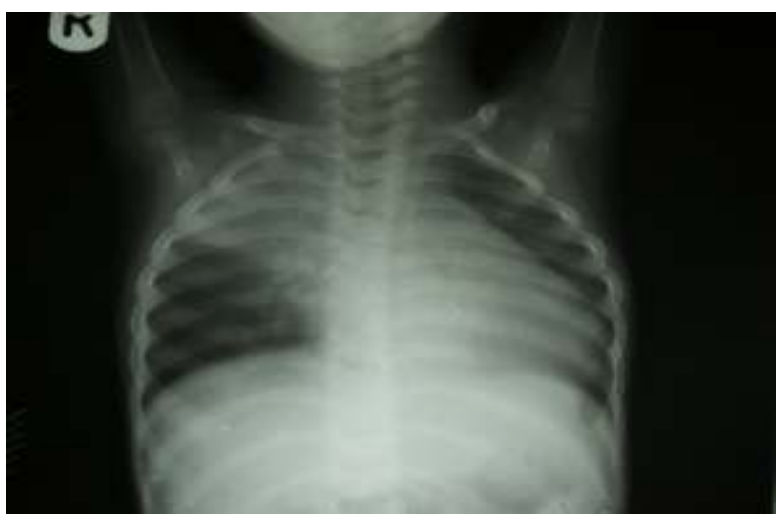

Figure 6: Chest radiograph in a 19 months old male child sh owing right upper lobe pneumonic consolidation

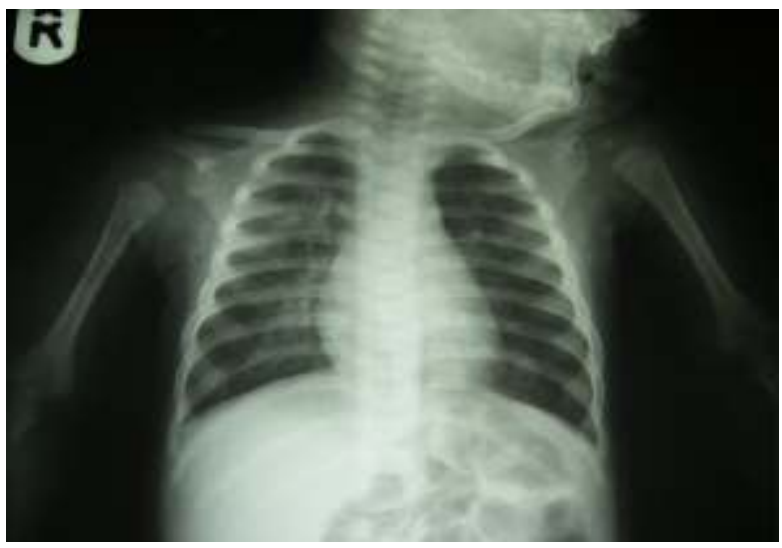

Figure 7: Chest radiograph of a 3 months old female child showing bilateral perihilar infiltrates worse on the right

the radiograph.

Plain chest radiographic examination may also direct additional diagnostic measures. ${ }^{3}$ When results of routine radiography are inconclusive computerized tomography (CT) is mandatory. ${ }^{2}$ CT scan, in view of its advantages of superior contrast resolution and cross sectional display can be helpful in the analysis of complex cases, particularly when radiographic evidence of associated central obstruction, cavitation, lymphadenopathy or empyema is equivocal. ${ }^{24}$, ${ }_{25}$ In the immunocompromised patient population, high resolution CT has been shown to be more sensitive than plain radiography in the detection of such pulmonary infections. ${ }^{24}$ The main snag of CT, however, is its cost, being the main reason why many patients may not have it done, although we did not have a functioning one during the period of this study.

\section{CONCLUSIONS}

Pneumonia remains a common cause of morbidity in childhood, especially in the developing world. Radiological examinations are useful in defining the nature and extent of disease. Seasonal variations exist in its incidence and so public health preventive measures should be intensified at such peak periods.

\section{REFERENCES}

1. Herold CJ, Sailer JG. Communityacquired and nosocomial pneumonia. Eur Radiol. 2004; 14 Suppl 3:E2-20.

2. Franquet T. Imaging of pneumonia: trends and algorithms. Eur Respir J. 2001; 18(1):196-208.

3. Sharma S, Maycher B, Eschun G. Radiological imaging in pneumonia: recent innovations. Curr Opin Pulm Med. 2007; 13(3):159-69.

4. Scrimini S, Junemann A, Luna CM. Community acquired pneumonia in the tropics. Curr Opin Pulm Med. 2007; 13(3):170-176.

5. Adegbola RA, Obaro SK. Diagnosis of childhood pneumonia in the tropics. Ann Trop Med Parasitol. 2000; 94(3):197-207.

6. Zar HJ, Madhi SA. Childhood pneumonia- progress and challenges. $\mathrm{S}$ Afr Med J. 2006; 96(9Pt 2):890-900.

7. WHO Global under-five mortality trend, 1980 - 2011 and gap for achieving MDG 4 target. Child Health: World Health 
Organisation, 2012.

8. Aderele WI, Johnson AW. Pneumonias. In: Azubuike JC, Nkanginieme KEO,eds. Paediatrics and Child Health in a Tropical region. 2nd ed. Owerri. African Educational Services. 2007; 425-441.

9. Adedoyin OT, Johnson WBR, Ojuawo A, Mokuolu OA, Ernest SK, Abdulkarim AA, Adesiyun OO, Adegboye OA, Adeboye MAN, Afolabi JK, Bidmus RM, Bello OA, Ayeni S. Distribution of major cases and major contributors to mortality at the department of paediatrics, University of Ilorin Teaching Hospital, Ilorin. Annual Paediatric Digest. 2010: 188.

10. Sa'ad YM, Hayatu A, Al-mustapha II, Orahachi YM, Makarfi HU. Morbidity and mortality in childhood illnesses at the emergency paediatric unit of a tertiary hospital, north-eastern Nigeria. Sahel Medical Journal. 2015;18 (1): 1-3.

11. Juvén T, Mertsola J, Waris M, Leinonen M, Meurman O, Roivainen M, Eskola J, Saikku P, Ruuskanen O. Etiology of community-acquired pneumonia in 254 hospitalized children.Pediatr Infect Dis J. 2000; 19(4):293-8.

12. Abhulimen-Iyoha BI, Okolo AA. Morbidity and mortality in childhood illnesses at the emergency paediatric unit University of Benin Teaching Hospital, Benin City. Niger J Paed. 2012;39 (2): 71 74.

13. Montgomery JL. Pneumonia. Pearls for interpreting patients' radiographs. Postgrad Med. 1991; 90(5):5866, 69-73.

14. Boersma WG, Daniels JM, Löwenberg A, Boeve WJ, van de Jagt EJ. Reliability of radiographic findings and the relation to etiologic agents in community-acquired pneumonia. Respir Med. 2006; 100(5):926-32. Epub 2005 Dec 6.

15. Ruuskanen O, Mertsola J. Childhood community-acquired pneumonia. Semin Respir Infect. 1999; 14(2):163-72.
16. Hortal M, Estevan M, Iraola I, De Mucio B. A population-based assessment of the disease burden of consolidated pneumonia in hospitalized children under five years of Textbook of Radiology and Imaging. 7th ed. Churchill Livingstone Elsevier. 2003: 247- 264.

18. Abdulkarim AA, Ibraheem RM, Adegboye AO, Johnson WBR, Adeboye MAN. Childhood pneumonia in the University of Ilorin Teaching Hospital, Ilorin Nigeria. Nigerian Journal of Paediatrics. 2013; 40 (3): 284-289.

19. Fagbule D, Adedoyin MA and Nzeh DA. Childhood pneumonia in the University of Ilorin Teaching Hospital. Nigerian Journal of Paediatrics. 1987; 14:73-78.

20. Oyejide CO, Osinusi K. Acute respiratory tract infection in children in Idikan Community, Ibadan, Nigeria: severity, risk factors, and frequency of occurrence. Rev Infect Dis. 1990; 12 Suppl 8: S 10421046.

21. Falade AG, Ayeni AI. Epidemiology, aetiology and management of childhood acquired community pneumonia in developing countries. Afr J Med Med Sci. 2011; 40 (4): 293-308.

22. Fagbule D, Parakoyi DB, Spiegel R. Acute respiratory tract infections in Nigerian children: prospective cohort study of incidence and case management. J. Trop Pediatr. 1994; 40(5): 279-284.

23. Cha PW, Chew FT, Tan TN, Chua KB, Hooi PS. Seasonal variation in respiratory syncytial virus chest infection in the tropics. Pediatr Pulmonol. 2002; 34(1): 47-51

24. Katz DS, Leung AN. Radiology of pneumonia. Clin Chest Med. 1999; 20(3): 549-62.

25. Vilar J, Domingo ML, Soto C, Cogollos J. Radiology of bacterial pneumonia. Eur $\mathbf{J}$ Radiol. 2004; 51(2):102-13. 